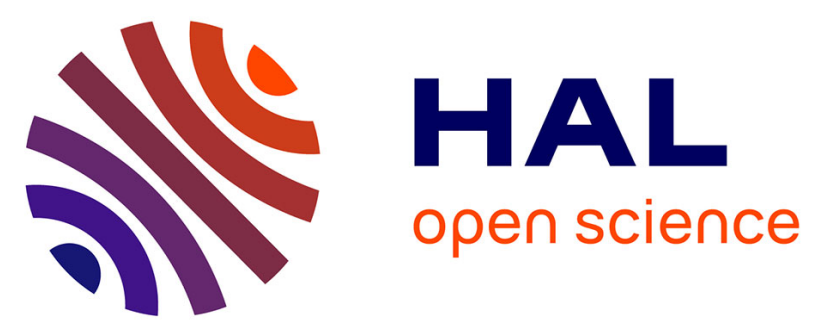

\title{
Is the variability of key wood properties linked with the variability of key architectural traits? Case of planted Teak in Togo regarding thinning and provenance
}

\author{
Kodjo Tondjo, Loïc Brancheriau, Sylvie-Annabel Sabatier, Adzo Dzifa \\ Kokutse, Arcadius Akossou, Kouami Kokou, Thierry Fourcaud
}

\section{To cite this version:}

Kodjo Tondjo, Loïc Brancheriau, Sylvie-Annabel Sabatier, Adzo Dzifa Kokutse, Arcadius Akossou, et al.. Is the variability of key wood properties linked with the variability of key architectural traits? Case of planted Teak in Togo regarding thinning and provenance. Annals of Forest Science, 2015, 72 (6), pp.717-729. 10.1007/s13595-014-0425-x . hal-01284205

\section{HAL Id: hal-01284205 https://hal.science/hal-01284205}

Submitted on 7 Mar 2016

HAL is a multi-disciplinary open access archive for the deposit and dissemination of scientific research documents, whether they are published or not. The documents may come from teaching and research institutions in France or abroad, or from public or private research centers.
L'archive ouverte pluridisciplinaire HAL, est destinée au dépôt et à la diffusion de documents scientifiques de niveau recherche, publiés ou non, émanant des établissements d'enseignement et de recherche français ou étrangers, des laboratoires publics ou privés. 


\title{
Is the variability of key wood properties linked with the variability of key architectural traits? Case of planted Teak in Togo regarding thinning and provenance
}

\author{
Kodjo Tondjo • Loïc Brancheriau • \\ Sylvie-Annabel Sabatier • Adzo Dzifa Kokutse • \\ Arcadius Akossou • Kouami Kokou • Thierry Fourcaud
}

Received: 12 August 2014 / Accepted: 10 September 2014 / Published online: 24 October 2014

(C) INRA and Springer-Verlag France 2014

\begin{abstract}
- Key message A retrospective architectural analysis performed on planted teaks in Togo showed that the variation of wood radial properties were linked with tree ontogeny, and that these relationships depended on thinning practices and provenance.

- Context Variability in growth, flowering and forking in individual trees according to origin and/or thinning practices may affect wood structure and consequently impact wood physical properties. We tested this hypothesis in teak.

- Aims We sought evidence of: (1) origin effects (Togolese versus Tanzanian teak) on growth, flowering, cambial growth and wood properties; (2) thinning effects on these variables
\end{abstract}

\section{Handling Editor: Jean-Michel Leban, Ph.D.}

Contribution of the co-authors Kodjo Tondjo collected field data, contributed to the data analysis and discussion and wrote the article. Sylvie-Annabel Sabatier, Loïc Brancheriau and Acardius Akossou helped in collecting field data, made the data extractions, performed statistical analyses and helped in writing the manuscript. Adzo Dzifa Kokutse, Kouami Kokou and Thierry Fourcaud supervised the whole project, participated in field data collection and helped in writing the manuscript.

K. Tondjo $\cdot$ L. Brancheriau $\cdot$ S.-A. Sabatier $\cdot$ T. Fourcaud $(\triangle)$ CIRAD, UMR AMAP (botAnique et bioinforMatique de l'Architecture des Plantes), TA A-51/PS2 Boulevard de le Lironde, 34398 Montpellier Cedex 5, France

e-mail: thierry.fourcaud@cirad.fr

K. Tondjo $\cdot$ A. D. Kokutse $\cdot$ K. Kokou

Faculté des Sciences, Département de Botanique, Université de

Lomé, Lomé, Togo

L. Brancheriau

CIRAD, UMR BioWooEB, Montpellier, France

A. Akossou

Faculté d'Agronomie, Université de Parakou, Parakou, Republic of Benin and (3) relationships between tree ontogeny and radial variations of wood properties.

- Methods A retrospective architectural analysis was used to draw stem growth and near infrared spectroscopy to assess radial variations of wood properties.

- Results Flowering reflects tree vigour and began at an earlier age in Togolese than in Tanzanian provenances. No differences were detected in regards to growth ring surface area, basic density and modulus of elasticity. Both systematic and selective thinnings improved growth without impacting the two latter properties. Stabilization of the growth ring area observed at 4 years old was associated with a decline in stem annual extension with a 1-year time lag.

- Conclusions Architectural analyses showed that radial growth was linked with tree ontogeny. This method can be extended to subsequent developmental stages, i.e. to older trees with economic interest, and used to determine architectural traits that are useful in tree selection.

Keywords Cambial growth $\cdot$ Ontogeny $\cdot$ Wood quality $\cdot$ Basic density $\cdot$ Tree architecture $\cdot$ Tectona grandis

\section{Introduction}

In Togo, planted forests cover approximately 50,000 ha (FAO 2009). Most are teak plots, which, today, represent the only opportunity to produce timber and multiple-purpose wood for the local market. It is estimated that teak plantations will reach approximately 150,000 ha by 2035 on the Togolese territory (FAO 2011). This species has therefore been the focus of a number of studies (Kokutse et al. 2004, 2005, 2009a, b; Logossa 2006) with the aim to increase and improve plantation productivity. Findings showed that technological properties (natural durability, wood colour, physical and mechanical 
traits) display considerable inter-individual and interplot variability, depending on ecological factors such as soil and climate (Kokutse et al. 2009b). On the other hand, interpopulation genetic diversity is very low (Logossa 2006). In spite of these research inputs, the current productivity level of teak plantations in Togo remains low and hardly meets the needs of the domestic market for wood products. Moreover, wood defects related to silvicultural practices, such as early forkings, are still seen. Genetic relationships between flowering and forking were found and are considered key to teak improvement strategies (Callister 2013). In teak, flowering is terminal on the axes as the apical meristem turns into an inflorescence. One or several lateral buds then take over to further the development of the axis. Initially, successive flowerings are followed by the development of a single-relay axis in the continuity of the stem, but at given time in the tree development, flowering is followed by the apparition of two dominant relay axes, thus creating a fork that determinates the height of the exploitable log (Leroy et al. 2009). In several species, tree growth, flowering and forking variabilities that depend on the plants' origin or on the thinning methods applied may affect the anatomy structure of the wood and consequently, its physical properties, thus ultimately impacting wood quality (Givnish 1988; Poorter et al. 2012), in particular, in Teak (Moya et al. 2014). According to these authors, stem volume increases after thinnings come with a reduction in wood density and modulus of elasticity, while other studies claim that the wood property alterations that appear after thinnings are only temporary and recede in a few years (Tasissa and Burkhart 1998). This is an important matter since it determines what strategy foresters must adopt to produce timber in the shortest time possible without impairing wood quality.

In all the studies mentioned above, the link between the variability of tree architecture and the variability of wood properties is not clearly established, despite the importance of morphological traits for tree breeding, pruning and thinning strategies in fast-growing plantations (Forrester et al. 2011). The aim of the present work is to answer this question on planted Teak in Togo, focusing on stem growth in length and flowering regarding tree architecture, and stem diameter growth, basic density and modulus of elasticity (MOE) regarding wood characteristics. The two following factors were considered for the study: (1) the origin of Teak, i.e. Togolese teak versus Tanzanian teak and (2) the thinning regime, i.e. selective versus systematic.

\section{Materials and methods}

\subsection{Study area and data collection}

The study was undertaken at the Agbavé forest station $\left(0^{\circ} 45^{\prime}\right.$ E, $6^{\circ} 43^{\prime} \mathrm{N}$ ) in southwestern Togo. Rainfall averages between
1100 and $1400 \mathrm{~mm}$ per year, with a peak in June. Mean maximum temperature ranges between 29 and $36^{\circ} \mathrm{C}$, and the hottest months are February and March. Mean minimum temperature ranges between 20 and $36{ }^{\circ} \mathrm{C}$, and the coolest months are July and August. There are two dry seasons: one from November to March and the other from July to September. The trees are without leaves during the main dry season (from November to March). Relative air humidity is close to $83 \%$ on average. Our study was carried out in four teak (Tectona grandis Linn. f., Lamiaceae) plots, located close together in order to minimize environmental effects (soil and climate) on the studied variables.

Three plots planted with Togolese teak were selected, representing different management practices. In addition, one plot planted with Tanzanian teak was considered for the provenance comparison. The teak termed 'Togolese' was introduced into Togo by the colonial administration at the beginning of the nineteenth century, whereas the 'Tanzanian' teak was introduced in the 1990s as seeds from Tanzania. The seedlings were originally planted at a density of 2500 trees/ha, i.e. at a $2 \times 2 \mathrm{~m}$ spacing for all plots. One Togolese teak plot $(T o S y)$ and the Tanzanian teak plot (TaSy) were planted in 2001 and underwent a systematic thinning intervention that eliminated systematically one in every two trees, thus halving the initial stand density (density after thinning equal 1250 trees/ha). The two other plots were planted in 2002. One of them $(\mathrm{ToSe})$ was submitted to a selective thinning (density after thinning equal 1000 trees/ha). The objective of selective thinning is to eliminate a number of less-promising stems to advantage the most promising individuals by giving them a more favourable environment (more than half of the initial population was removed). The other plot (ToCo) was left unthinned as a control plot. Thinning was performed at an age of 7 years old for all thinned plots. The effects of the thinning operations were investigated on Togolese trees only. Measurements were taken during the November 2011 dry season (10 years old for ToCo and ToSe and 11 years old for ToSy and TaSy), i.e. approximately 3 years after the thinning operation, in order to compare the impact of the different thinning practices. In each plot, 20 trees were selectedaccording to their distribution in the diameter classes and among the trees that had experienced the least accidentsand felled (80 trees examined in total).

All tree data analyses were performed with regard to developmental stages (ontogeny) instead of years as classically used in forest research. This approach was relevant in this study, as all plots did not have the same age at the time of field measurement. Moreover, it was assumed that climate conditions were not too variable between years in the studied region, which makes the comparison of development stages available.

Three cross-section samples (disk samples) were extracted from each stem in the middle of chosen growth units (making 
a total of 240 disks) in order to characterize the variability of the studied variables in relation to elevation within the tree. One disk sample was taken in the first growth unit (GU1) at the base of the stem, a second disk was cut in the second growth unit (GU2), and a third disk was collected in the fourth growth unit (GU4; Fig. 1b). This last choice allowed getting information higher in the stem compared to the third GU. The fifth GU was generally located above the first main branch (reiteration) and then was not collected. The height of a given GU was variable from one tree to another according to $\mathrm{GU}$ length distribution and was not measured.

\subsection{Architectural measurements}

A retrospective analysis of tree growth was carried out on all 80 sampled trees. This retrospective analysis was based on architectural observations (Barthélémy and Caraglio 2007; Taugourdeau et al. 2012). The architectural approach allows the development dynamics to be drawn from germination to the actual growth stage through the analysis of growth morphological markers, e.g. growth units (GU) and flowering (Fig. 1a).

The identification of morphological markers of meristem activity is a way to reconstitute a posteriori the growth history of an individual tree (Barthélémy and Caraglio 2007). On the younger axes of the felled individuals, the scars left by the cataphylls that make up the buds' outer components can still be seen, making it possible to locate the halts in growth. However, the scars left by the various leaf organs fade out on older portions of the stem and it then becomes much more difficult to reliably locate all the pauses in growth. Counting growth rings was then used to back up the morphological examination, to check the existence of each pause and to delimit precisely the successive growth units (GUs). With this pre-analysis, we confirmed that the teaks studied produce a single growth unit per year. Once the growth units delimited, we were able to measure their successive lengths and basal diameters along the entire stem. Growth units are numbered consecutively from the base of the tree upwards and terminal flowerings and forks were assigned according to the rank of GU. The number of GUs produced before the first flowering and the first forking was recorded. The height of the first flowering/fork equates to the cumulative length of the successive growth units that precede it along the main stem (Fig. 1). The total cumulated length is the sum of the lengths of all the successive growth units of the main stem (Xplo software suite from AMAPstudio, Griffon and de Coligny 2014). The tree architecture variables analysed were: the cumulated length of the successive growth units of the main stem, the diameter at breast height $(\mathrm{DBH})$ of the stem, the height of the first flowering and the number of GUs produced and the height of the first fork and the number of GUs produced.

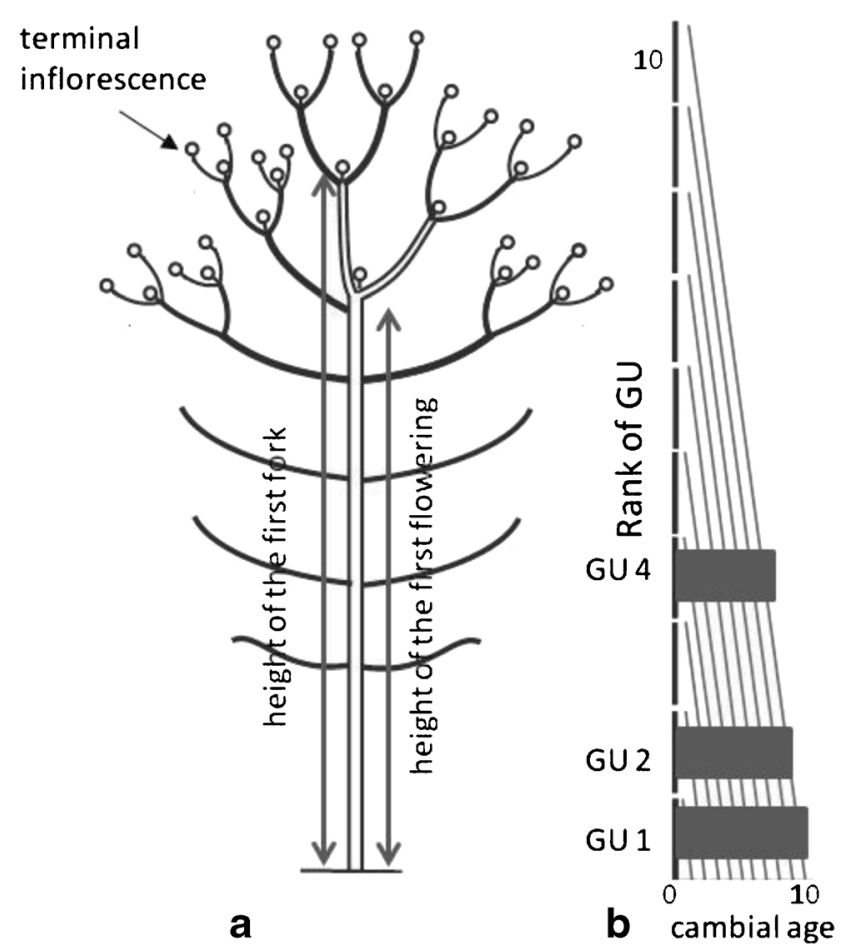

Fig. 1 Measurement and sampling methods. a Schematic representation of teak architecture with location of the first fork and of the first flowering; b location of the three disk samples within the stem according to the rank of growth unit

2.3 Growth ring surface area, wood density and modulus of elasticity measurements

For logistical reasons, each one of the 240 cross-sections sampled was sawn down to a $30-\mathrm{mm}$ wide strip across its greatest diameter. One side of each strip was then sandpapered and digitized (300 dpi, 48 bits) for measuring the growth ring surface area. Growth ring surface area was considered equivalent to the area of an annulus and estimated with the formula $A=\pi\left(R^{2}-r^{2}\right)$. The outer and inner radii (respectively, $R$ and $r$ ) of the rings were measured using the ImageJ software. Near infrared spectroscopy was used to assess specific wood properties (basic density and elasticity modulus) every $5 \mathrm{~mm}$ from pith to bark along the 240 growth ring samples. Choosing this quick, reliable and non-destructive method turned out to be determinant (Baillères et al. 2002; Schimleck et al. 2003). By analysing the scanned images of the samples, we were able to match the radial position with the position of the annual increments. The wood properties pertaining to each growth ring are thus equal to the mean of the linearly interpolated values to the $1 / 10 \mathrm{~mm}$ between the inner and outer limits of the ring. The regression models of the near infrared spectroscopy were calibrated on the basis of 44 growth ring samples selected according to their distribution in the diameter classes. A total of 143 wood specimens (RTL dimensions: $15 \times 15 \times 45 \mathrm{~mm}$ ) were sawn and stabilized at $20{ }^{\circ} \mathrm{C}$ and $65 \%$ relative humidity. Infrared spectroscopy 
measurements were taken first, followed by basic density (oven dry weight divided by saturated volume; saturated volume assessed using Archimedes' principle) and longitudinal modulus of elasticity. Modulus of elasticity values were estimated through ultrasound propagation measurements ( $1 \mathrm{MHz}$ transducers in direct contact with the specimen, with Poisson's ratios considered negligible). To compare the two provenances, we based ourselves on the ten, nine and seven growth rings of GU1, GU2 and GU4, respectively. Analysis of thinning effects on radial growth and specific wood properties was based on the ultimate three growth rings of each crosssection of stem, i.e. the three growth rings produced after the thinning intervention.

\subsection{Statistical analyses of data}

Tree data, i.e. tree architecture and wood properties, were analysed based on an ontogenic approach. This approach consists in a retrospective rebuilding of tree growth, which allows comparing trees at the same developmental stage. In particular, ring data were analysed with regard to cambial age instead of calendar year. This choice is usual when studying the ontogenetic variability, which refers to the elapsed time after germination, and to compare trees that were not planted at the same year.

To study 'origin' and 'thinning practice' effects on tree architecture and specific wood properties, the ANOVA was conducted on two different scales: (1) at the scale of the tree $(N=80)$, the effects were studied over six variables (height of first flowering, number of growth units before the first flowering, height of first fork, number of growth units before the first forking, total cumulated length of the successive growth units along the main stem and $\mathrm{DBH}$ ) with taking into consideration only the first 10 years of growth; (2) at the scale of the growth unit (GU1, GU2 and GU4), the effects were studied over three variables (surface area, basic density and modulus of elasticity of the growth rings). To compare the two provenances, we based ourselves on the ten, nine and seven growth rings of GU1, GU2 and GU4, respectively; the number of observations taken into account in the analysis differed depending on the GU considered: 20 trees $\times 2$ plots $\times 10$ growth rings $=400$ for GU1; 20 trees $\times 2$ plots $\times 9$ growth rings $=360$ for GU2 and 20 trees $\times 2$ plots $\times 7$ growth rings $=$ 280 for GU4. Analysis of thinning effects on radial growth and specific wood properties was based on the ultimate three growth rings of each cross-section of stem, i.e. the three growth rings produced after the thinning intervention. The number of observations was 120 i.e. 20 trees $\times 2$ plots $\times 3$ growth rings for all the three growth (GU1, GU2 and GU4). At the scale of the growth units, the information linking individual data points to individual trees disappears and the set of growth units are considered as belonging to the 'plot' population. In this way, the ANOVA took into account both inter- and intra-tree variabilities, whereas it would have only taken into account inter-tree variability if the mean per tree had been calculated beforehand.

\section{Results}

3.1 Effects of provenance on tree architecture and wood properties

Wood properties (basic density and modulus of elasticity) were determined using regression models of the near infrared spectroscopy. The cross-validation method (with ten random segments) leaded to a $R_{\mathrm{CV}}^{2}$ of 0.84 (root-meansquare error of cross-validation (RMSECV) of $25 \mathrm{~kg} / \mathrm{m}^{3}$ ) for the basic density model and a $R^{2}$ CV of 0.87 (RMSECV of $1573 \mathrm{MPa}$ ) for the modulus of elasticity model. No significant difference in diameter was found between the two provenances. However, the cumulated length of successive GUs along the main stem is significantly greater in Togolese teak $(1012 \pm 129 \mathrm{~cm})$ than in Tanzanian teak $(882$ $\pm 135 \mathrm{~cm}$; Table 1). Height of first flowering and of first fork was similar in both provenances, but it must be noted that there is a significant effect of the provenance on the age (i.e. the number of GUs produced) at first flowering and at first forking. The mean age at first flowering is 5 years in Togolese teak, versus 7 years in Tanzanian teak. Forks also tend to develop at an earlier age in Togolese teak, at 6 years on average, against 8 years in Tanzanian trees. It appears that a length growth threshold must be reached before flowering is triggered, this threshold being similar regardless of origin. The threshold is reached at approximately 5 years in trees of Togolese provenance, and at 7 years in Tanzanian teaks (Fig. 2a). Our findings show that the effect of provenance on mean growth ring surface area is non-existent in GU1, but strong in both GU2 and GU4. At the base of the tree, mean ring surface area of Togolese and Tanzanian teaks are practically the same ( 940 \pm 644 and $892 \pm 647 \mathrm{~mm}^{2}$, respectively). Further up along the stem, mean growth ring surface area becomes significantly greater in Togolese trees $\left(553 \pm 446 \mathrm{~mm}^{2}\right.$ for GU2 and $352 \pm 192 \mathrm{~mm}^{2}$ for GU4) than in Tanzanian trees (452 \pm $261 \mathrm{~mm}^{2}$ for GU2 and $277 \pm 146 \mathrm{~mm}^{2}$ for GU4) with, however, high variability of values along the stem. Growth ring surface area tends to decrease with the successive GUs from stem base to stem tip. In regards to basic density and modulus of elasticity, no significant differences were found between same-rank GUs of different provenances. Variability of basic density and modulus of elasticity according to GU rank along the stem is very low. Heartwood was present in GU1 and GU2 but not in all GU4. 


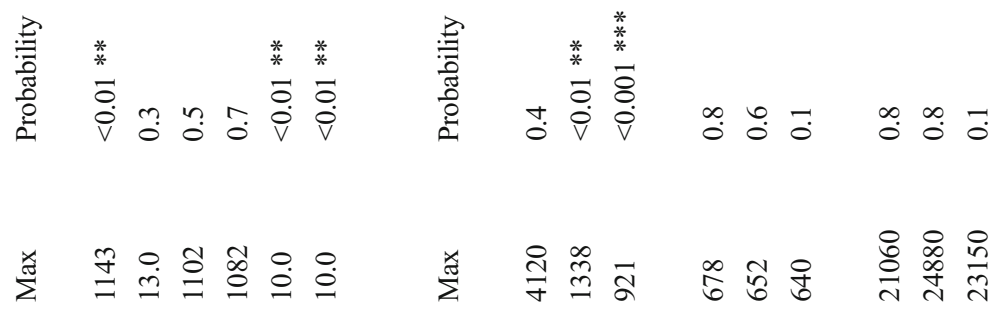

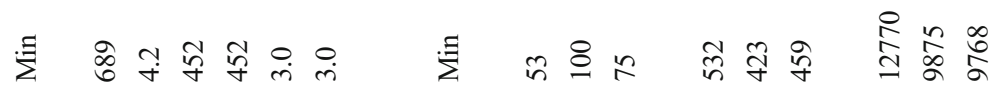

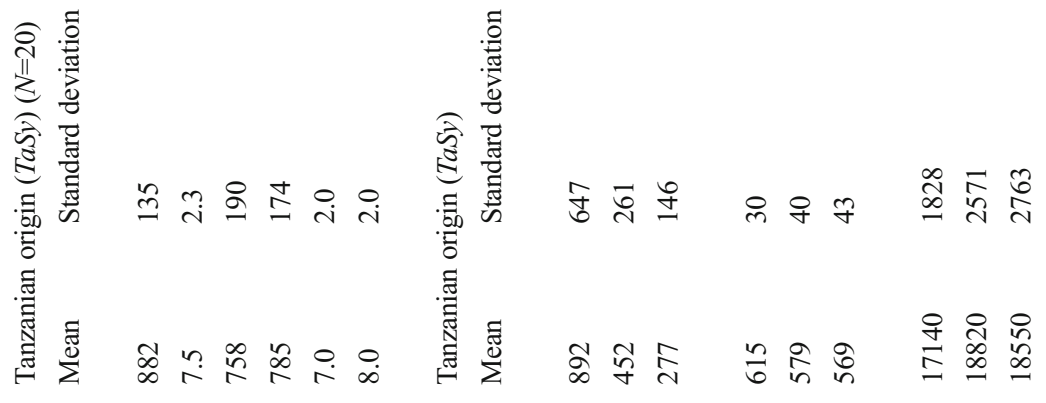

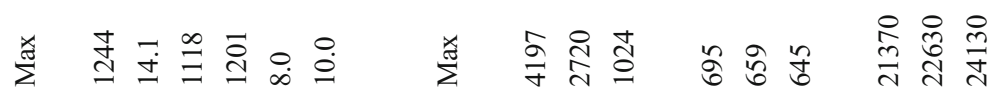

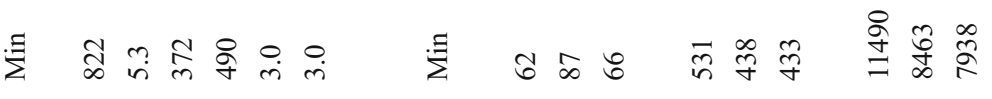

产.

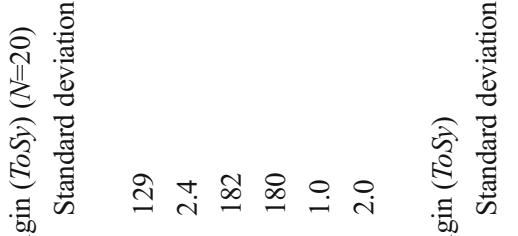

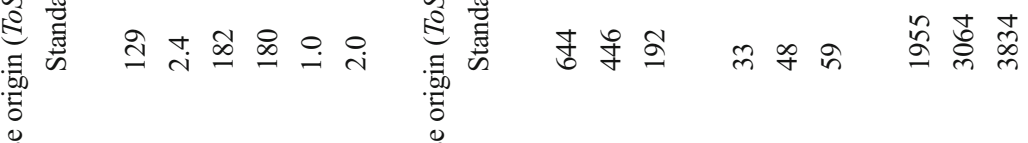

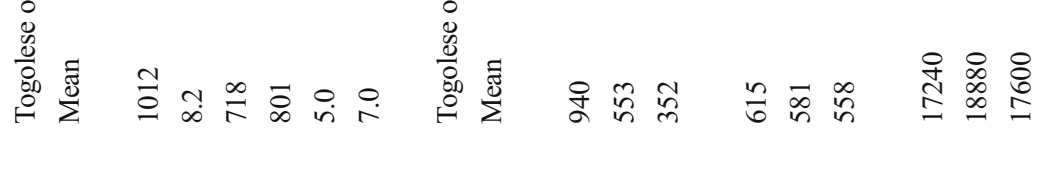




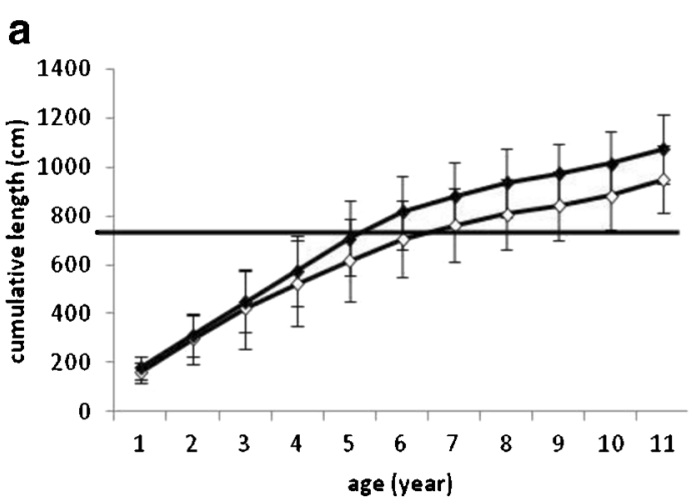

Fig. 2 Main stem extension for white diamonds Tanzanian and black diamonds Togolese teaks: a Mean cumulative length and standard deviation of GUs against tree age; the horizontal line is the length growth

\subsection{Effects of systematic thinning on tree architecture} and wood properties

The cumulated length of the main stem's successive GUs differs significantly in the systematically thinned plot ToSy $($ mean $=1012 \pm 129 \mathrm{~cm})$ and in the control plot ToCo (mean= $873 \pm 151 \mathrm{~cm}$ ) (Table 2). On the other hand, diameters, heights of first flowering and heights of first fork are similar in both plots. Regarding the number of years (i.e. the number of GUs produced) before the first flowering or forking, the difference between the two plots is significant: first flowering and forking occur, respectively, at 7 and 8 years, respectively, in ToCo, and at 5 and 7 years in ToSy. Mean surface area of growth rings in GU2 is significantly higher in the trees of ToSy ( $501 \pm 320$ versus $367 \pm 224 \mathrm{~mm}^{2}$ in the control), but no significant difference in mean ring surface area was recorded in the case of GU1 and GU4. Variability of mean growth ring surface area per GU fluctuates markedly all along the main stem and decreases strongly from the base upwards. No significant difference in mean basic density of growth rings was found between ToCo and ToSy in growth units 1, 2 and 4 alike. Mean modulus of elasticity was found to be equivalent in the two plots in both GU1 and GU2; but in GU4, it was significantly higher in the trees from the systematically thinned plot $(20,440 \pm 1878 \mathrm{MPa})$ than in those from the control $(18,510 \pm 2626 \mathrm{MPa})$ : at this height, the systematic thinning treatment tends to increase the elasticity modulus. Variability of basic density in relation to GU rank seemed very low, whereas that of the modulus of elasticity was high. Overall, the modulus of elasticity is greater towards the top of the stem than at its base.

3.3 Effects of selective thinning on tree architecture and wood properties

Cumulated length of GUs on the main stem, tree DBH and height of the first fork are all significantly different in ToCo $(873 \pm 151,6.8 \pm 2.1$ and $799 \pm 146 \mathrm{~cm}$, respectively) and in

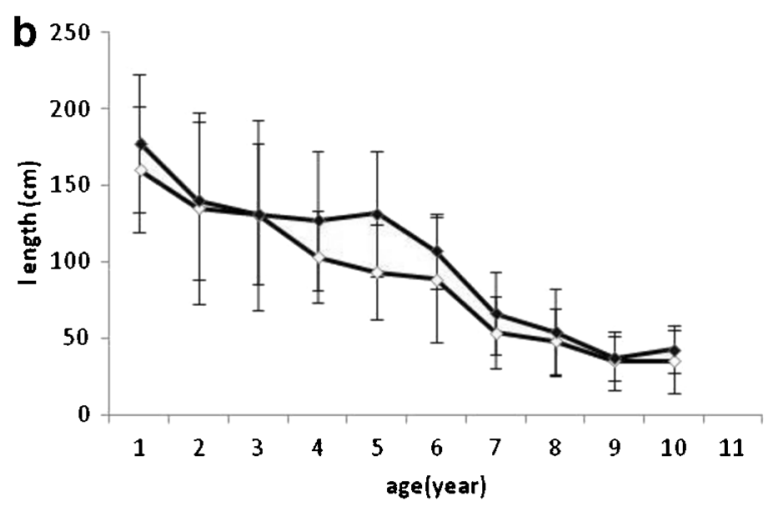

threshold for onset of flowering; $\mathbf{b}$ Mean length and standard deviation of the successive GUs in the main stem against tree age

ToSe $(1074 \pm 130,8.4 \pm 2.1$ and $911 \pm 193 \mathrm{~cm})$ (Table 3). Selective thinning improves length growth, radial growth and height of the first forking, but does not seem to affect height of first flowering nor age (i.e. the number of GUs) at first flowering or forking. Mean growth ring surface area of GU4 is not significantly different in selectively thinned trees and in control trees. Considering all sample trees per plot, we, however, found that for GU1 and GU2, significant differences in the mean surface area of growth rings between ToSe $(978 \pm$ 613 and $518 \pm 376 \mathrm{~mm}^{2}$ for GU1 and GU2, respectively) and ToCo $\left(713 \pm 689\right.$ and $\left.367 \pm 224 \mathrm{~mm}^{2}\right)$. The high standard deviation obtained for GU1 is probably due to the proximity of buttresses at the stem base, which introduce a bias in the measurement of the largest diameter. The variability of mean growth ring surface area is very high between GUs along the main stem. Mean surface area of rings decreases with successive GUs from base to tip. The ANOVA did not uncover any difference between the ToSe and ToCo in terms of basic density, whether in GU1, GU2 or GU4. Similarly, the modulus of elasticity of GU1 and GU2 did not seem to be affected by selection thinning. However, this treatment does have a significant effect on the mean modulus of elasticity of growth rings in GU4. Mean values are $21,130 \pm 2388 \mathrm{MPa}$ in ToSe versus $18,510 \pm 2626 \mathrm{MPa}$ in the control plot. Mean growth ring basic density exhibits very low variability from one $\mathrm{GU}$ to the next along the main stem, whereas modulus of elasticity values tends to increase from stem base to stem tip.

\subsection{Effects of position in the tree architecture on length} and radial growths and wood properties

Cambial growth (growth ring area) increases during the first 4 years and then decreases. This trend was noted on the examined cross-sections of GU1, GU2 and GU4 alike (Fig. 3). Basic density increases progressively over the first five growth rings and then stabilizes, and this was observed in all three analysed positions (Fig. 3). On the other hand, annual cambial growth and basic density are greater in GU1 than in 


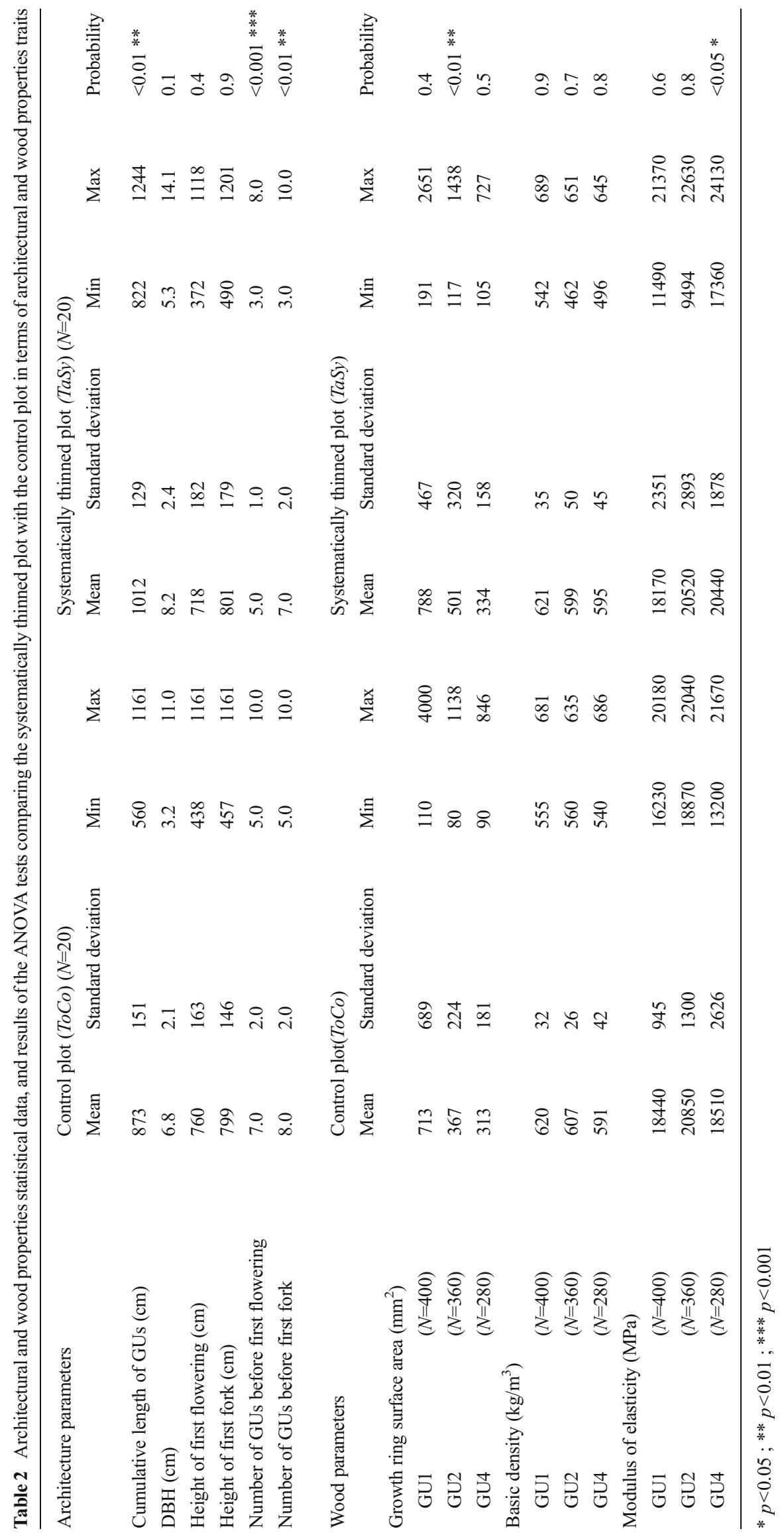




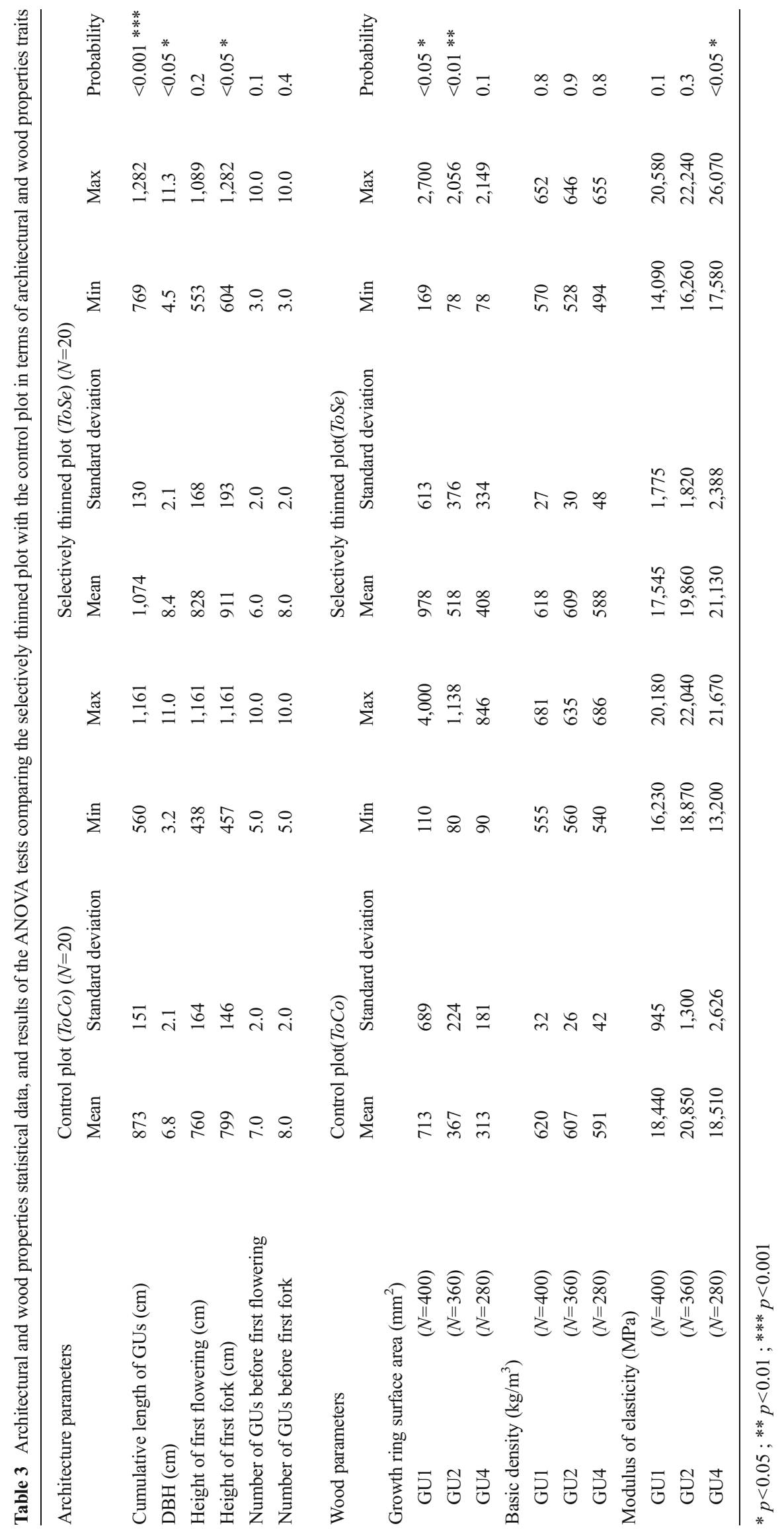


both GU2 and GU4. The annual length growth (length of successive growth unit) decreases in the second growing year, then relatively stabilized during some years and progressively decreases. The trend is similar between both provenances with a delay of occurrence (Fig. 2b).

\section{Discussion}

We used the retrospective approach to draw main stem growth and to study the effects of tree provenance and thinning practices on the dynamics of teak growth and on the physical and mechanical properties of the wood in relation to cambial age. An innovative method for studying wood properties was also tested in this study and used to produce new results.

4.1 Dynamic relationships between tree ontogeny and radial variations of wood physical properties

In teaks of either provenance, annual cambial growth is characterized by a progressive increase, followed by a stable phase and then by a phase of gradual decline with increasing cambial age. Radial observation of cambial growth suggests that the initial gradual increase over the first 4 years of growth corresponds to the progressive increase of the primary growth during the first steps of the tree ontogeny or 'base effect' (Barthélémy and Caraglio 2007). A decrease of length growth between first GU and followed GUs of the main stem suggests a transplantation effect. In our study area, the 1-year-old saplings are cut back at transplantation and one axillary shoot with a high length then develops into the main stem. In trees of either provenance and in all three positions in the tree architecture, growth ring surface area begins to wane as from the fourth year. This trend reflects the ageing of the cambium. When the annual radial growth and annual length growth are analysed conjointly, the results suggest that the progressively increase of growth ring area over the fourth growing year positively impacts the annual length growth of the main stem with a 1-year time lag. This relationship is explained by the hypothesis that the enhanced secondary growth facilitates water availability and consequently, the primary bud growth (Cochard et al. 2005).

The basic density radial variation profile differs from the ring surface area profile. The first growth ring exhibits markedly lower basic density values than the following. Basic density values then tend to increase over the next 3 years, and then stabilize from the fifth year onwards in the three growth units examined. This radial variation of basic density in relation to cambial age is well known in teak (Bhat and Priya 2004; Pérez and Kanninen 2005) and is more generally a trend resulting from wood formation in trees (Plomion et al. 2001). The phase of basic density buildup is characteristic of juvenile wood, whereas the stabilized state is the one found in mature wood (Zobel and Van Buijtenen 1989). According to Moya et al. (2009), the juvenile stage was established in 56 year olds utilizing anatomical features and this result agreed with our results. It is often mentioned in the literature that juvenile wood is formed within the tree crown, when adult wood is formed in the pruned part of the stem below the tree crown (Zobel and Sprague 1998). The presence of reaction wood, which can locally influence wood properties, was not considered in this study. However, disk samples were circular and the rings were concentric enough to assume that this effect was negligible.

Basic wood density is considered as an important indicator of wood mechanical performances. Strong relationships between wood density and basic wood mechanical properties, e.g. modulus of elasticity, module of rupture or stress proportional limit were found by Betancur et al. (2000) for 13-yearold teak grown in Colombia. In Costa Rica, the average values of dry wood density found by Pérez and Kanninen (2003) varied from 500 to $650 \mathrm{~kg} \mathrm{~m}^{-3}$. These values are similar to those found in the present study and to those reported elsewhere for plantation-grown teak (Kandya 1974; González et al. 1979; Sanwo 1987; Bhat 1995; Vallil 1997; Brennan and Radomiljac 1998; Baillères and Durand 2000; Betancur et al. 2000; Bhat 2000).

\subsection{Provenance effects}

Togolese and Tanzanian teaks resemble each other in terms of diameter at breast height (DBH), but the former exhibit greater cumulated GU lengths than the latter. Moreover, the radial growth of the higher GUs (i.e. GU2 and GU4) is greater in trees of Togolese origin. Since wood infradensity is not significantly different in the two origins, Togolese teak allocates more dry biomass to its main axes. This finding leads us to consider three hypotheses: (1) at the age considered, Togolese teaks have mobilized more photosynthates overall for their development; (2) the extra photosynthate allocation to the main axes is done at the expense of the development of secondary axes and flowers and (3) the local kinetics of radial growth, which is related to the time evolution of the total surface of leaves connected upstream within the crown topology (see pipe model theory, Shinozaki et al. 1964), differs between the two provenances.

These hypotheses could be tested through a more in-depth study of the architecture of the crowns, drawing on tree biomass production and allocation models such as the GreenLab model (Yan et al. 2004), which may be used to research photosynthate source-sink dynamics in plants with complex architectures. Height of first flowering and height and time of first fork are not influenced by origin. In walnut, a tree with terminal flowering, it was shown that the height of the first fork reflects the local environment (Barthélémy et al. 

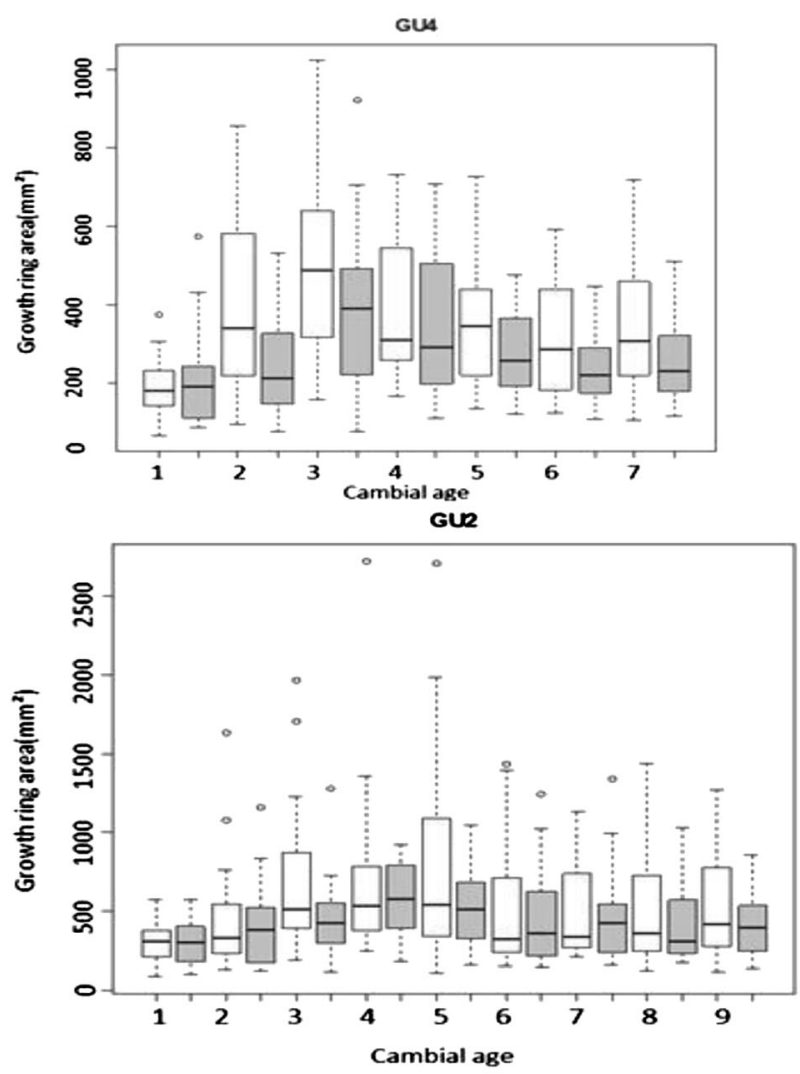

GU1

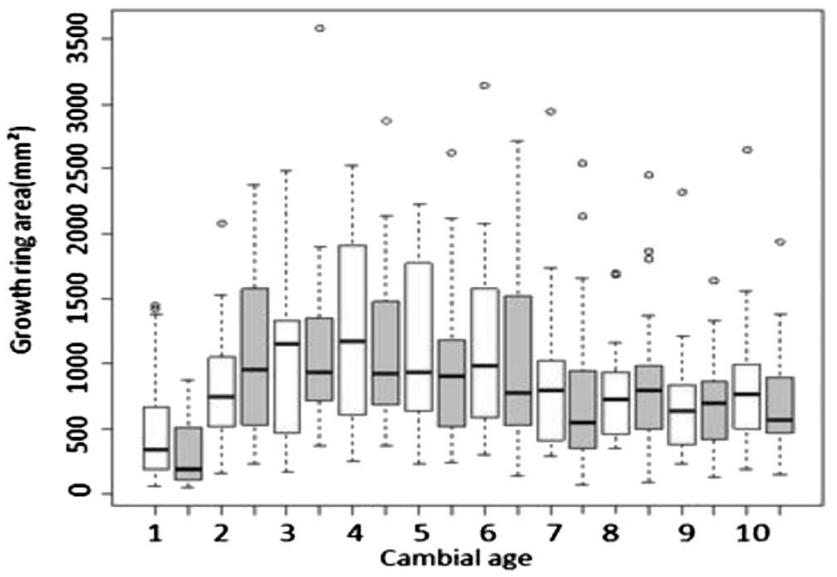

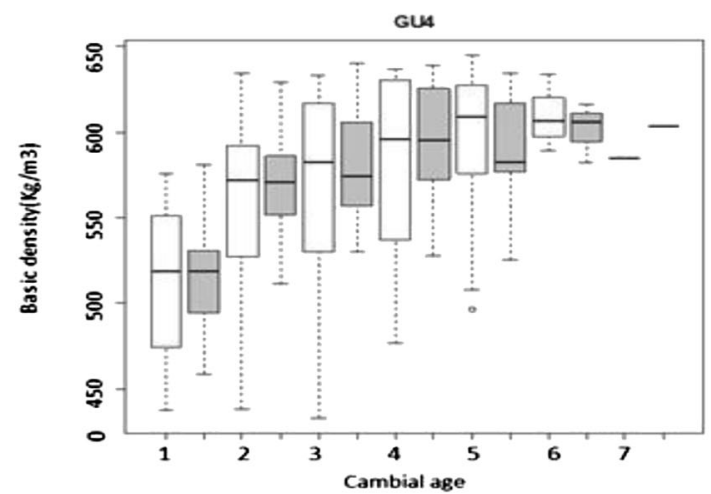
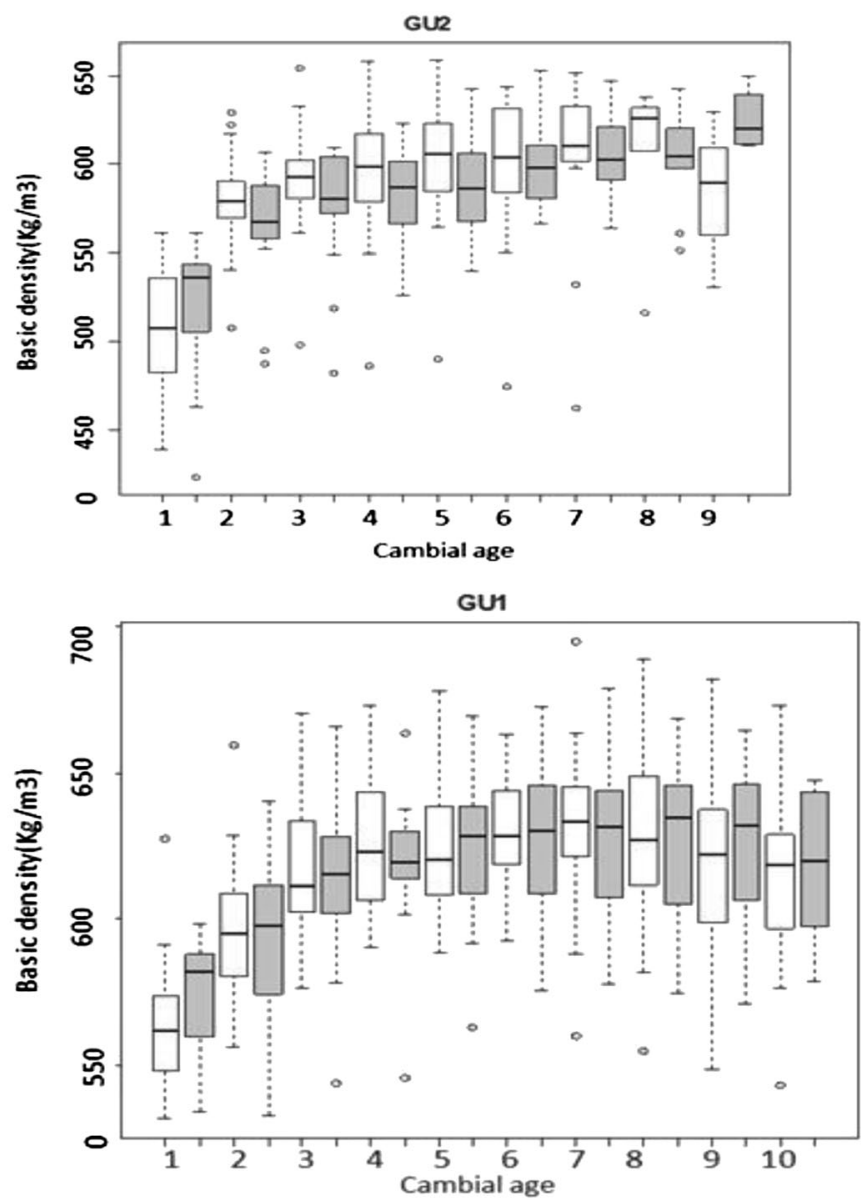

Fig. 3 Boxplots of successive growth rings (cambial age) area $\left(\mathrm{mm}^{2}\right)$ and basic density $\left(\mathrm{kg} / \mathrm{m}^{3}\right)$ at three levels in the main stem (GU1, GU2 and GU4) for Togolese teak (white box) and Tanzanian teak (grey box)

2009). In the case of teak, it appears that locally originating trees flower and fork earlier in life, i.e. after producing a smaller number of growth units. This suggests that the length growth threshold is the same in both origins, that it depends on the local environment and that the time needed to reach this threshold is influenced by the tree's origin and genotype. Our results support those of a genetic study involving several teak origins that revealed a strong genetic control over flowering age, whereas this control was weak to moderate over the height and age of the first forking (Callister 2013). Considering that Togolese teak is the best performer in terms of length growth, flowering could turn out to be a sign of vigour, since we observe that it is the tree that grows the fastest in height that also flowers the earliest. Such a relationship has also been found by Barthélémy (1988) in his study on flowering in Noisettia longifolia. His findings indicate that the flowering of an axis only takes place after a growth threshold of a certain number of internodes has been reached. Similar types of threshold effects have been documented in several species with terminal flowering (Lauri and Terouanne 1991). Growth ring surface area measurements in the first growth unit (GU1) show no effect of tree origin. The same goes for diameter at 
breast height (DBH). The high correlation between these two variables is explained by the fact that in most cases, the first growth unit exceeds $1.30 \mathrm{~m}$, which means that DBH is generally measured on GU1. Moreover, the results show that Tanzanian and Togolese teak have very similar basic density and elasticity modulus values in the studied growth units. As the lifespan of secondary order branches is similar between the two provenances, the location (in the topological sense) of any GU with regards to crown base is the same for all trees at any growth step. According to the hypothesis of juvenile wood formation within the tree crown mentioned in the previous section, radial transition between juvenile and mature wood would occur at the same period in all trees, whatever their provenance.

Few studies have dealt with the physical and mechanical characteristics of West African plantation teaks (Kokutse et al. 2004). In Togo, the investigations that addressed this topic revealed that these wood characteristics exhibit considerable inter-individual and interplot variability (Kokutse 2002). The observed variabilities seem more related to environmental parameters than to interpopulation genetic diversity (Logossa 2006). This is confirmed by our findings, which highlight that these particular traits are not influenced by tree origin. According to the work of Poorter et al. (2012) in particular, the tree branching mode and the allometry of its main axes are linked by functional relationships and are strongly influenced by abiotic constraints such as gravity. In our study, since all the plots were located at the same station, site effects were minimized and it may be hypothesized that the differences in wood properties that were recorded between the two origins mostly relate to genotypic characteristics.

\subsection{Effects of thinning practices}

The ANOVA results highlight a significant effect of systematic thinning on cumulated longitudinal growth, age at first flowering and age at first forking. No effect of systematic thinning was found on radial growth variables (DBH and annual growth ring surface area), height at first flowering, height at first forking, infradensity and elasticity modulus. This means that systematic thinning is not necessarily useful to improve radial growth, commercial log length and wood quality. The fact that the tree diameter and the growth ring surface area are practically the same in systematically thinned plots and in control plots is surprising because it is usually considered that stand density significantly affects tree radial growth in Teak (Moya et al. 2014). Other studies have reported the positive impacts of thinning interventions on tree growth, such as a faster growth of individual trees (Zeide 2001). A positive effect of selective thinning was noted on both length and radial growth. This may be explained by the fact that selective thinning eliminates sick and deformed individuals, thus redistributing the stand's potential over the most vigorous and best-performing trees. Moreover, by removing more than $50 \%$ of the stand's trees, the selective thinning operation greatly increased the spacing between some individuals, thus alleviating competition (Zahner and Whitmore 1960). Thinning increases light, water and nutrient availability to each individual as these resources are shared among fewer trees. Improved light conditions boost tree growth (Mayor and Rodà 1993; Pérez and Kanninen 2005) through enhanced photosynthetic activity, while a better-lit forest floor also stimulates root development (Zobel and Van Buijtenen 1989). The ANOVA showed no significant difference between controls and selectively thinned trees in terms of mean growth ring basic density values. This contradicts the findings of Barbour et al. (2003), according to which wood produced on thinned plots is much less dense than that produced on unthinned plots. In addition, Pérez and Kanninen (2005) found the highest wood basic density in the highest stand densities (light thinnings). Pérez and Kanninen (2003) also noted that variations within thinning treatments negatively affected the relationship between wood basic density and stand density in teak plantations located in different regions of Costa Rica. Our own observation that the growth improvements obtained through selective thinning do not come at the expense of wood quality is of particular interest to wood users and forest managers.

\section{Conclusion}

The results of this study show that at the age of teak studied, systematic thinning has a greater effect on primary growth unlike radial growth. Compared to the systematic thinning, selective thinning promotes both height and radial growth without altering the specific wood properties studied (growth ring surface area, basic density and elasticity modulus). This result clearly demonstrates the potential that may have a selective thinning in terms of improved tree growth without reducing the quality of teak wood. The optimization of merchantable volume by controlling stand density (thinning) should depend on species, site and stand age. Regarding provenance effect, the results show correlations between radial variations and tree ontogeny. This information is useful as it can help provide architectural traits for tree breeding. Such knowledge can also be used to develop and fit structuralfunctional growth model of teak, for instance, using GreenLab formalism (Yan et al. 2004). GreenLab model is used to study the dynamic of sources and sinks of assimilates in plants of complex architecture and, in that way, can provide complementary quantitative key insights in order to develop teak ideotypes. GreenLab simulations, in addition to the actual results, can also be performed in order to analyse and predict the effect of pruning on growth reallocation in teak, following 
a methodology previously applied to cotton plants (de Reffye et al. 1999). From the practical point of view, this study must be extended to older teaks in order to extrapolate these results to ages of economical interest. Wood quality is indeed less important for teaks less than 10 years old, as those studied here, which are mainly exploited for fuel wood or fence posts.

Acknowledgments AMAP (Botany and Computational Plant Architecture) is a joint research unit which associates CIRAD (UMR51), CNRS (UMR5120), INRA (UMR931), IRD (2M123), and Montpellier 2 University (UM27); http://amap.cirad.fr/. The authors thank the owner of the experimental plots, Professor Messanvi GBEANSSOR at University of Lomé and the Lome University's students for their help in the measurements of the field.

Funding This work has been carried out in the framework of the Tecksim project funded by the AUF-PCSI programme and is a part of Tondjo Kodjo's Ph.D. thesis (grant from CIRAD AIRD).

\section{References}

Baillères H, Durand PY (2000) Non-destructive techniques for wood quality assessment of plantation-grown teak. Bois et Forêts des Tropiques 263:17-29

Baillères H, Davrieux F, Ham-Pichavant F (2002) Near infrared analysis as a tool for rapid screening of some major wood characteristics in a eucalyptus breeding program. Ann For Sci 59:479-490

Barbour RJ, Marshall DD, Lowell EC (2003) Managing for wood quality. In: Monserud, et al. (eds) Compatible For Man. 299-336

Barthélémy D (1988) Architecture et sexualité chez quelques plantes tropicales : le concept de floraison automatique. Thèse de Doctorat (physiologie et biologie des organismes et des populations). Montpellier : Université des Sciences et Techniques du Languedoc, France

Barthélémy D, Caraglio Y (2007) Plant architecture: a dynamic, multilevel and comprehensive approach to plant form. Structure and ontogeny. Ann Bot 99:375-407

Barthélémy D, Caraglio Y, Sabatier S (2009) Crown architecture of valuable broadleaved species. In Spiecker H, Hein S, MakkonenSpiecker K, Thies M (eds). Valuable broadleaved forests in Europe. Leiden: Brill (European Forest Institute Research Reports, vol. 22)

Betancur CA, Herrera JF, Mejía LC (2000) Study on the physical and mechanical properties, workability and seasoning of teak in Puerto Libertador. (Estudio de las propiedades físicas y mecánicas, trabajabilidad y secado de la teca (Tectona grandis) de Puerto Libertador (Córdoba). Rev Fac Nac Agron Medellín 56:913-939

Bhat KM (1995) A note on heartwood proportion and wood density of 8year-old teak. Indian Forester 121:514-516

Bhat KM (2000) Timber quality of teak from managed tropical plantations with special reference to Indian plantations. Bois et Forêts des Tropiques 263:6-15

Bhat KM, Priya PB (2004) Influence of provenance variation on wood properties of teak from the Western Ghat region in India. IAWA J 25: 273-282

Brennan GK, Radomiljac AM (1998) Preliminary observations on the utilization and wood properties of plantation teak (Tectona grandis) and African mahogany (Khaya senegalensis) grown near Kununurra, Western Australia. Austrailian For 61:120-126

Callister AN (2013) Genetics parameters and correlations between stem size, forking, and flowering in teak (Tectona grandis). NRC Res Press 43:1145-1150
Cochard H, Coste S, Chanson B, Guehl JM, Nicolini E (2005) Hydraulic architecture correlates with bud organogenesis and primary shoot growth in beech (Fagus sylvatica). Tree Physiol 25:1545-1552

de Reffye P, Blaise F, Chemouny S, Jaffuel S, Fourcaud T, Houllier F (1999) Calibration of a hydraulic architecture-based growth model of cotton plants. Agronomie 19:265-280

FAO (2009) Forest resources assessment 2009: tropical forest plantation resources, D. Pandey. Etude FAO Forêts $n^{\circ} 128$. Rome, Italy

FAO (2011) Situation des forêts du monde. FAO, $110 p+$ Annexes. Rome

Forrester DI, Collopy JJ, Beadle CL, Baker TG (2011) Effect of thinning, pruning and nitrogen fertiliser application on light interception and light-use efficiency in a young Eucalyptus nitens plantation. For Ecol Manag 288:21-30

Givnish TJ (1988) Adaptation to sun and shade, a whole plant perspective. Aust J Plant Physiol 15:63-92

González G, Bonilla L, Rivera D (1979). Properties and uses for teakwood growing in Quepos, Costa Rica. (Propiedades y usos dela madera de teca creciendo en Quepos, Costa Rica). Laboratorio de Productos Forestales, Universidad de Costa Rica

Griffon S, de Coligny F (2014) AMAPstudio: an editing and simulation software suite for plants architecture modelling. Ecological Modelling. Available on line http://dx.doi.org/10.1016/j.ecolmodel. 2013.10.037

Kandya AK (1974) Weight dynamics in immature Anogeissus, Tectona and Terminalia. Indian Forester 100:93-100

Kokutse AD (2002) Analyse de la qualité du bois de teck (Tectona grandis L.f) en plantation au Togo : formation du bois de coeur, propriétés mécaniques et durabilité. $\mathrm{PhD}$ thesis, Université Bordeaux I, France

Kokutse AD, Baillères H, Stokes A, Kokou K (2004) Proportion and quality of heartwood in Togolese teak (Tectona grandis L.f). Forest Ecol Manag 189:37-48

Kokutse AD, Stokes A, Baillères H, Baudasse C, Kokou K (2005) Heartwood and natural decay resistance in plantation grown teak (Tectona grandis L.f.) from Togo, West Africa in quality timber products of teak from sustainable forest management. Bhat K.M., Nair KKN, Bhat KV, Muralidharan EM and Sharma JK (Eds). Peechi, Kerala Forest Research Institute, India, pp 297-302

Kokutse AD, Adjonou K, Kokou K, Gbeassor M (2009a) Problématique de la performance du teck de provenance tanzanienne par rapport au teck local en plantation au Togo. Bois et Forêts des Tropiques 302: $43-52$

Kokutse AD, Adjonou K, Kokou K (2009b) Relationship between ecological indicators and teak wood. Int J Biol Chem Sci 3: 483-491

Lauri PE, Terouanne E (1991) Eléments pour une approche morphométrique de la croissance végétale et de la floraison : le cas d'espèces tropicales du modèle de Leéuwenberg. Can J Bot 69: 2095-2112

Leroy C, Sabatier S, Wahyuni NS, Barezi JF, Dauzat J, Laurans M, Auclair D (2009) Virtual trees and light capture: a method for optimizing agroforestry stand design. Agrofor Syst 77: $37-47$

Logossa ZT (2006) Caractérisation génétique des Tecks (Tectona grandis L.f.) provenant de plantations du Togo. Master II, Sciences du Bois et Fibres, Université Bordeaux I, France

Mayor X, Rodà F (1993) Growth response of Holm oak (Quercus ilex L) to commercial thinning in the Montseny mountains (NE Spain). Forestry 50:247-256

Moya R, Berrocal A, Serrano R, Tomazello M (2009) Radial variation of anatomical features, wood density and decay resistance in teak (Tectona grandis) from two qualities of growing sites and two climatic regions of Costa Rica. For Syst 18:119-131

Moya R, Bond B, Quesada-pineda H (2014) A review of heartwood properties of Tectona grandis trees from fast-growth plantations. Wood Sci Technol 48:411-433 
Pérez LD, Kanninen M (2003) Heartwood, sapwood and bark content, and wood dry density of young and mature teak (Tectona grandis) trees grown in Costa Rica. Silva Fenn 37:45-54

Pérez LD, Kanninen M (2005) Effect of thinning on stem form and wood characteristics of teak (Tectona grandis) in a humid tropical site in Costa Rica. Silva Fenn 39:217-225

Plomion C, Leprovost G, Stokes A (2001) Wood formation in trees. Plant Physiol 127:1513-1523

Poorter L, Lianes E, Moreno-de las Heras M, Zavala MA (2012) Architecture of Iberian canopy tree species in relation to wood density, shade tolerance and climate. Plants Ecol 213:707-722

Sanwo SK (1987) The characteristics of the crown-formed and stemformed wood in plantation grown teak in Nigeria. J Inst Wood Sci $11: 85-88$

Schimleck LR, Mora C, Daniels R (2003) Estimation of the physical wood properties of green Pinus taeda radial samples by nearinfrared spectroscopy. Can J For Res 33:2297-2305

Shinozaki K, Yoda K, Hozumi K, Kira T (1964) A quantitative analysis of plant form; the pipe model theory,1. Japan J Ecol 14:97-105
Tasissa G, Burkhart HE (1998) An application of mixed effects analysis to modeling thinning effects on stem profile of loblolly pine. Forest Ecol Manag 103:01

Taugourdeau O, Dauzat J, Griffon S, Sabatier S, Caraglio Y, Barthélémy D (2012) Retrospective analysis of tree architecture in silver fir (Abies alba Mill.): ontogenetic trends and responses to environmental variability. Ann For Sci 69:713-721

Vallil G (1997). Utilization of teak. Proceedings International Teak Symposium 175-178

Yan HP, Kang MZ, De Reffye P, Dingkuhn M (2004) A dynamic, architectural plant model simulating resource-dependent growth. Ann Bot 93:591-602

Zahner R, Whitmore FW (1960) Early growth of radically thinned loblolly pine. J Forestry 58:628-634

Zeide B (2001) Thinning and growth. J Forestry 99:20-25

Zobel BJ, Sprague JR (1998) Juvenile wood in trees. Springer Series in Wood Science. Heidelberg, Berlin

Zobel BJ, Van Buijtenen JP (1989) Wood variation, its causes and control. Springer Verlag, Berlin, p 363 